\title{
A INFLUÊNCIA DA DISCIPLINA DE PSICOLOGIA NA FORMAÇÃO PROFISSIONAL E SOCIAL DOS ACADÊMICOS DE CIÊNCIAS CONTÁBEIS DA UNEMAT DE TANGARÁ DA SERRA - MT
}

\author{
Sibele Rodrigues Belo ${ }^{1}$
}

\section{RESUMO}

Este artigo teve por objetivo identificar a percepção dos acadêmicos do curso de Ciências Contábeis sobre a influência que os conhecimentos proporcionados pela disciplina de Psicologia exercem na formação do profissional contábil tal como na rotina pessoal. Através de pesquisa de campo, com questionários aplicados aos acadêmicos do $4^{\circ}, 5^{\circ}, 6^{\circ}, 7^{\circ}$ e $8^{\circ}$ semestre do curso de Ciências Contábeis da Universidade do Estado de Mato Grosso UNEMAT - Campus de Tangará da Serra-MT, constatou-se que os estudantes imputam seriedade aos assuntos do comportamento humano de forma a considerarem a disciplina de Psicologia como um aperfeiçoamento educacional. A importância revelada pelos discentes às questões abordadas pela Psicologia para formação profissional e pessoal dos futuros contadores evidenciou para UNEMAT o quanto a disciplina de Psicologia é significativa para os graduandos.

PALAVRAS-CHAVE: Ensino Superior. Comportamento. Contabilidade.

\section{INTRODUÇÃO}

As empresas, para sobreviverem no mercado em contexto atual, dependem entre outros fatores da atuação dos colaboradores para obter sucesso e lucratividade. Fundamental, então, que haja um bom convívio entre os colaboradores e seus respectivos gestores, sendo assim é necessário que o indivíduo sinta-se equilibrado para relacionar-se com as pessoas ao seu redor e, de igual forma, consigo mesmo (CHIAVENATO, 2006).

Quantas vezes no nosso dia-a-dia tentamos compreender as atitudes do nosso colega de trabalho, dos nossos pais, da nossa (o) esposa (o), dos nossos filhos e até mesmo as nossas próprias atitudes? A Psicologia pode auxiliar em tais respostas, pois é ciência que busca estudar o comportamento humano e contribui no desenvolvimento de técnicas para lidar com as pessoas e ao mesmo tempo entendê-las de um modo mais amplo. A Psicologia Organizacional e do Trabalho são um campo de atuação desta ciência que tem sido bastante evidenciado neste último século, de modo a compreender o comportamento do homem em

\footnotetext{
${ }^{1}$ Acadêmica do Curso de Ciências Contábeis, da Universidade do Estado de Mato Grosso Campus Universitário de Tangará da Serra - UNEMAT, belinha15_@hotmail.com;
} 
situação de trabalho, assim como traçar estratégias organizacionais no que se refere aos recursos humanos (SPECTOR, 2002).

O perfil de um Profissional Contábil exige que ele desenvolva habilidades e conhecimentos abrangentes, atuais e específicos. Portanto, para uma boa gestão dentro de uma organização é importante que o contador também domine os aspectos que abrangem a área de Psicologia. Ela auxiliará nos processos organizacionais através da compreensão dos modos de agir das pessoas sem julgamento precipitado, e, principalmente, incentivando a motivação e satisfação em ambiente de trabalho, entre outros fatores (FREITAS, 2011).

Sendo assim, este trabalho baseado em fundamentos teóricos, busca discutir a afirmativa de que nos dias atuais a Psicologia é fundamental para a rotina de um profissional contábil, tanto no aspecto profissional quanto social e individual.

Os fatores principais que levaram a escolha deste tema foram a afinidade com os conteúdos apresentados na disciplina de Psicologia Organizacional no decorrer da graduação, assim como o relacionamento interpessoal diário nesta Universidade. Estabeleceu-se a partir daí o problema que norteia a presente investigação: Qual a influência da disciplina de Psicologia para a formação profissional e social dos futuros contadores da UNEMAT de Tangará da Serra-MT segundo os acadêmicos de Ciências Contábeis?

O objetivo geral da investigação que aqui se apresenta foi identificar qual a influência da disciplina de Psicologia na formação do profissional contábil, conforme apontado pelos próprios acadêmicos do curso, tão somente identificar o que modificou na vida pessoal e profissional dos acadêmicos após cursar a disciplina de Psicologia Organizacional. Quanto aos objetivos intermediários, o estudo buscou ainda oportunizar aos acadêmicos a reflexão sobre a Psicologia como ferramenta de auxilio no desenvolvimento individual e profissional na carreira de Ciências Contábeis. Os dados foram coletados através de questionário, com perguntas fechadas, dirigido aos acadêmicos do $4^{\circ}$ ao $8^{\circ}$ semestre do curso de Ciências Contábeis da UNEMAT, Campus de Tangará da Serra - MT, cuja intenção foi caracterizar o acadêmico, assim como identificar a relevância de como percebem a disciplina de Psicologia no seu curso e os possíveis usos de suas ferramentas para o ambiente e rotina de trabalho.

\section{REFERENCIAL TEÓRICO}

Nesta seção, o artigo apresenta inicialmente o desenvolvimento da Contabilidade quanto a sua história como campo de saber científico, o perfil do profissional desta área e sua gestão na UNEMAT no município de Tangará da Serra - MT como curso de graduação. Em 
seguida, destaca-se o conceito da Psicologia, tal como um breve histórico deste campo de estudos como Ciência, relatando suas perspectivas para o profissional contábil em se considerando o recorte da Psicologia Organizacional e do Trabalho.

\subsection{Desenvolvimento da Contabilidade}

A Contabilidade existe desde a antiguidade, uma vez que desde o século IV a.C. os homens já controlavam seus bens e animais, através de marcas em árvores e até mesmo através de pedras, representando a quantidade de bens que possuíam, podendo controlar e conferir seus bens em termos de crescimento, perdas etc. Esta etapa da Contabilidade foi denominada de fase empírica da Contabilidade (IUDÍCIBUS, MARION, 2007).

Segundo A.P. Contabilidade (2011), a Contabilidade foi se desenvolvendo juntamente com a matemática até que se tornou uma necessidade para o controle monetário. Com a queda do feudalismo as compras de propriedades privadas aumentaram e com o descobrimento da América os países europeus enriqueciam cada vez mais. Em meados do século XV, o considerado pai da contabilidade Frei Luca Pacioli, marca o início da fase moderna da contabilidade com sua obra denominada "Summa de arithmetica, geometrica, proportioni et proportionalitá", na qual trata da escrituração por partidas dobradas e dos lançamentos contábeis (débitos e créditos). A obra de Pacioli foi um grande passo para contabilidade, além de auxiliar séculos depois a Igreja e o Estado com conceitos contábeis (SCHMIDT, 2000).

A Contabilidade chegou às universidades em meados do século XVII e com a Revolução Industrial começaram a surgir especialistas na área. Os empresários sentiram a necessidade de profissionais com conhecimentos mais abrangentes de Ciências Contábeis. Mas, só foi com a industrialização Norte Americana que contadores britânicos levaram tal profissão para América. Assim, com abertura de novas empresas multinacionais e mais movimentações de capitais, a profissão de Ciências Contábeis vem se expandindo (A.P CONTABILIDADE, 2011).

\subsection{Ciências Contábeis na UNEMAT Campus de Tangará da Serra - MT}

Conforme informa o site oficial do Curso de Ciências Contábeis (2011), o curso foi criado ainda sob a responsabilidade de oferta pelo CESUT - Centro de Ensino Superior de Tangará da Serra. No ano de 1995 conforme Resolução n 010-94 da Fundação Universidade do Estado de Mato Grosso e através da autorização do CEE-MT - Conselho Estadual de Educação, o Governo do Estado de Mato Grosso, através da UNEMAT - Universidade do 
Estado de Mato Grosso, encampou os cursos ofertados por esta instituição incluindo o curso de Ciências Contábeis. Com tal fato, o curso passou a desenvolver com uma melhor estrutura de forma mais organizada, e em 15 de setembro de 1995 foi inaugurado o Departamento de Ciências Contábeis no Campus Universitário de Tangará da Serra.

Com nova política de funcionamento, tendo em vista os princípios do Ensino, Pesquisa e Extensão, foram realizados vários eventos que marcaram o curso na sua história até o contexto atual. No final de 1997 foi realizado a "I Semana de Ciências Contábeis" da Unemat em Tangará da Serra, com intuito de levar novos conhecimentos aos acadêmicos, e até os dias atuais este evento tem prosperado, sendo que no ano de 2010 já se realizou a VII edição deste evento. No inicio de 2002 inaugurou-se o Laboratório Contábil, com doze microcomputadores e dois programas de Contabilidade: o Mastermaq e o Gecon, visando a atualização e oferta aos acadêmicos de novos recursos para proporcionar melhores qualidades na formação do profissional contábil (DEPARTAMENTO DE CIÊNCIAS CONTABEIS/UNEMAT, 2011).

Ainda em 2002, os Cursos de Graduação de Ciências Contábeis passam a participar do ENC-Exame Nacional de Cursos, o conhecido "PROVÃO", no qual o curso de Tangará da Serra foi avaliado e conseguindo alcançar a nota "C", considerada satisfatória para as condições do curso ainda jovem. O curso teve sua Matriz Curricular modificada com aprovação da Resolução no 044/2002 - CONEPE de 26/07/2002, de modo que a partir de 2003/1 o curso passou a ser ofertado em 04 anos e não mais em 05 anos (DEPARTAMENTO DE CIÊNCIAS CONTABEIS/UNEMAT, 2011).

Em 2006, por meio de parceria entre a Universidade do Estado de Mato Grosso com o Governo do Estado de Mato Grosso, o Departamento de Ciências contábeis passou a participar do projeto Centros de Excelência em Comércio Exterior - CECOMEX. Este projeto atua como corretora e consultoria para assuntos de exportação e importação em Tangará da Serra e região, além de oferecer cursos e palestras com assuntos de interesse nesta área (DEPARTAMENTO DE CIÊNCIAS CONTABEIS/UNEMAT, 2011).

Em sua história de existência, em termos de demanda para vestibular, o curso de Ciências Contábeis tem sido um dos cursos mais concorridos na UNEMAT de Tangará da Serra, segundo informa o site da Covest - Comissão de Vestibulares da UNEMAT, registrando aumento 2,4 candidatos disputando cada vaga ofertada nos últimos três anos. Em 2008/1 foram inscritos 374 concorrentes para as 50 vagas ofertadas pela instituição, equivalente a 7,48 candidatos disputando cada vaga. No vestibular de 2011/1 os inscritos 
foram 495, equivalente a 9,9 candidatos por vaga. Embora, nos últimos três anos analisados, os números de acadêmicos formandos caíram e os números de acadêmicos desistentes e com trancamentos aumentaram, em 2011/1 o curso foi o mais concorrido do município de Tangará da Serra, conforme noticiado pelo jornal Notícia Exata em abril de 2010 (DEPARTAMENTO DE CIÊNCIAS CONTABEIS/UNEMAT, 2011).

Conforme informações do site do Departamento de Ciências Contábeis (2011), em 2011 o curso conta com 38 professores distribuídos nas diferentes disciplinas do curso, sendo 16 deles Bacharéis em Ciências Contábeis. Em se tratando de outras áreas de formação, o curso contam com 05 Bacharéis em Matemática e Estatística, 10 Bacharéis dos cursos de Direito, Administração e Informática, 2 Bacharéis em Economia e 05 profissionais das Ciências Humanas. Desse quadro é importante registrar que há 15 docentes com título de Mestre e 03 Doutores.

O campo de atuação do profissional contábil por ser amplo e inovador vem sendo desenvolvido satisfatoriamente, abrangendo assim vários ramos específicos. O site oficial do departamento contábil da UNEMAT informa alguns deles: Contabilidade Financeira, Contabilidade de Custos, Auditoria Interna ou Externa, Perícia Contábil, Professor, Empresário Contábil, Analista, Investigador de Fraudes Contábeis, entre outros.

O Projeto Político Pedagógico do curso de Ciências Contábeis da UNEMAT de Tangará da Serra aponta alguns elementos que definem o perfil do contador graduado na instituição, conforme segue: Ter conhecimento técnico e científico para exercer a atividade contábil: tanto em micro e pequenas empresas (se for trabalhar como empregado), se adquirir o próprio escritório, ou se optar em trabalhar de forma independente; Ter competência: no momento da análise contábil, visualizar o mercado interno e externo, juntamente com a economia, além de outros fatores fundamentais que são indispensáveis para uma análise severa; Estar capacitado: ser habilidoso com outros setores e equipes dentro das organizações; Estar consciente: deverá estar sempre atualizado com legislação, regulamentos, normas etc., estando consciente para uma auto-crítica equivalente a sua potencialidade de execução; Exercer a profissão: sobretudo com ética e dar satisfação da gestão para sociedade; Ter formação: Humanística, fazendo com que o profissional compreenda o habitat em que convive (DEPARTAMENTO DE CIÊNCIAS CONTABEIS/UNEMAT, 2011).

Portanto, para que o profissional contábil obtenha sucesso em sua carreira é necessário que esteja aberto a novos conhecimentos, sendo qualificado, atualizado, etc. além de 
enquadrar ao perfil exigido pelo mercado global. Para Pinto (2011) o profissional contábil tem que possuir as seguintes características para ser bem sucedido: Criatividade; Desenvoltura; Capacidade de resolver problemas; Visão gerencial; Ousadia; Liderança; Trabalho em equipe; Motivação; Flexibilidade; Profundo conhecimento contábil, entre outras.

Assim, é interessante o estudo da Psicologia que abrange tais características, a ponto de desenvolvê-las e aplicá-las satisfatoriamente nas organizações, seja profissional de Ciências Contábeis ou não. Este assunto tratará no decorrer deste trabalho.

\subsection{Conceito da Psicologia}

A maioria dos psicólogos considera a Psicologia como "ciência do comportamento humano", a qual estuda os processos mentais e expressões comportamentais sejam elas visíveis ou não (FIORELLI, 2004). Para compreender a diversidade com que a Psicologia se apresenta hoje é fundamental e indispensável que conheçamos sua evolução histórica.

Segundo Braghirolli et al (1998) o homem sempre buscou explicações acerca de si mesmo, até mesmo antes que existisse uma ciência que se ocupasse disso. Os autores ainda afirmam que entre os primitivos, principalmente, as explicações eram de origem sobrenatural, sendo que só no século VI a.C Tales de Mileto propôs explicações dos fenômenos naturais em função de outros eventos naturais. Sócrates, Platão e Aristóteles foram os pensadores gregos que, de acordo com Bock, Furtado e Teixeira (2000) tiveram grande influência no aparecimento da Psicologia como ciência, através de suas teorias sobre a divisão da alma e do corpo.

Na Idade Média os estudos para compreensão do indivíduo humano em todas as suas dimensões sofreram grande impacto, tendo em vista que nesta época a Igreja Católica impedia qualquer atividade que fosse contrária a Deus como criador e fonte de explicação de mundo. Tal fato incidiu no que é conhecido como decadência grega (BERGAMINI, 1982). É a partir desta época que surge o conjunto da palavra grega psyché, que significa alma, e de logos, que

significa razão surgindo então à palavra Psicologia. Bock, Furtado, Teixeira esclarecem que mesmo com a intervenção da Igreja Católica, na Idade Média, surgiram nesta época escolas filosóficas que favoreceram de certa forma as futuras escolas psicológicas. Outros fatores foram diferenciais no estabelecimento da Psicologia como ciência. No século XIX, surge a Fisiologia com os avanços nos estudos das funções cerebrais, e a Psicofísica, que buscava estudar as relações existentes entre a mente e os estímulos do corpo físico. 
Segundo Prestes (2003, p.23) em sentido restrito "ciência não se refere a qualquer tipo de conhecimento, mas aquele que aprende ou registra os fatos, demonstrando-os por suas causas constitutivas ou determinantes". A Psicologia tornou-se ciência no ano de 1879 através da inauguração de seu primeiro laboratório de Psicologia Experimental na Universidade de Leipzig, na Alemanha, por Wilhelm Wundt (1832 - 1920), conforme aponta Braghirolli et all (1998).

Mais tarde, por volta de 1900, John B Watson (1878 - 1959) estrutura a teoria do Behaviorismo, propondo um objeto estritamente observável para a Psicologia: o comportamento. De acordo com Bock, Furtado e Teixeira (2000), Watson dispensou os estudos sobre a mente e sua função, afirmando que somente através da análise científica do comportamento que se poderiam tirar considerações finais concretas e científicas a respeito do comportamento humano. Já em oposição ao Estruturalismo e o Behaviorismo nasce, também nos Estados Unidos, a Gestalt, uma escola de pensamento de origem alemã que entende o estudo do comportamento humano considerando-se o contexto como um todo. Para os gestaltistas a análise cientifica do comportamento acaba por destituir de sentido o fenômeno estudado. Outro movimento muito importante que se destacou ainda no final do século XIX e permanece até hoje é a Psicanálise. Segundo Braghirolli et al (1998) este campo de estudos foi proposto por Sigmund Freud (1856 - 1939), médico clínico, que procurou origens mentais dos comportamentos. Para Freud o individuo humano tem influências conscientes e inconscientes no seu modo de agir, sendo que o inconsciente é a parte da mente que merece maior atenção ao se estudar o comportamento humano.

A Psicologia tem várias áreas de atuação, porém três delas se destacam: A Psicologia Clínica, que estuda maneiras de lidar com problemas humanos social, como relacionamento interpessoal etc.; A Psicologia Escolar, que se ocupa de trabalhar as questões relacionadas aos processos escolares, como a alfabetização, o fracasso escolar, a educação de deficientes etc. também cabe a este ramo da Psicologia se ocupar de processos de gestão escolar. E a Psicologia Organizacional, que pode ser considerada como a intermediadora da organização e as relações entre as pessoas (BOCK, FURTADO, TEIXEIRA, 2000), sobre o qual se tratará mais detalhadamente a seguir.

\subsection{Psicologia Organizacional}

A Psicologia Organizacional surgiu no século XX, embora suas raízes de pensamento sistematizado se situem no século XIX. Desenvolveu-se através de cientistas experimentais, 
os quais tinham curiosidade em aplicar princípios da Psicologia em áreas das organizações, sendo que os dois principais estudiosos foram Hugo Munsterberg e Walter Dill Scott (SPECTOR, 2002). O trabalho fundamental para Psicologia Organizacional desenvolveu-se através de Frederick Winslow Taylor, que propôs e definiu a "administração científica", cujos princípios se caracterizam como essenciais para o desenvolvimento de técnicas organizacionais. Em seus princípios, Taylor defendeu que os funcionários devem ser treinados com cautela para exercer suas atividades, além de serem recompensados para incentivar melhores desempenhos futuros, entre outros (SPECTOR, 2002).

Conforme Spector (2002, p. 05), A Psicologia Organizacional "refere-se ao desenvolvimento e à aplicação de princípios científicos no ambiente de trabalho”. Assim, os psicólogos organizacionais não têm envolvimento direto com os problemas emocionais e pessoais do funcionário, mas, quando necessário, identificam desequilíbrios comportamentais e encaminham o individuo a um clinico especialista.

Como toda ciência, a Psicologia tem seus objetivos e conseqüentemente define seus desígnios, no caso deste trabalho, os que se referem às organizações. Fiorelli (2004) aponta os seguintes objetivos desta ciência: Estabelecer as leis básicas da atividade psicológica para não causar conseqüências como desgastes emocionais e custos desnecessários; Estudar meios de evolução no ambiente organizacional quanto à compreensão pelos administradores dos processos que os envolve; Desvendar os mecanismos que lhe servem de apoio para os fatos que surgem a partir do senso psicológico, exemplo, stress; Identificar as alterações psicológicas que acorrem no individuo a partir das modificações estruturais e funcionais do próprio, exemplo, alcoolistas que se tornam mais tendenciosos a perda de produtividade.

Segundo Bergamini (1982, p.20), o objetivo da Psicologia do comportamento organizacional é "aprofundar-se no estudo do homem em situação de trabalho de forma generalizada". Segundo a autora é fundamental um administrador ter uma base de conhecimento psicológico para assim poder caracterizar cada ser humano com o qual se relaciona em situação de trabalho. Do mesmo modo a Psicologia proporciona a compreensão dos conflitos que possam se produzir na empresa, além de poder visualizar as mudanças e as medidas que devem ser tomadas para uma melhoria organizacional ou pessoal.

O comportamento das pessoas dentro da organização depende de alguns fatores essenciais de recursos humanos, que segundo Chiavenato (2006, p.63) se dividem em dois fatores: 
Fatores internos (decorrentes de suas características de personalidade, como capacidade de aprendizagem, motivação, percepção do ambiente interno e externo, atitude emoções, valores etc.) e fatores externos (decorrentes do ambiente que as envolve, das características organizacionais, como sistemas de recompensas e punições, fatores sociais, políticas, coesão grupal existente etc.)

Conforme o Chiavenato (2006) afirma, os fatores internos estão mais ligados a motivação sendo tudo que incentiva a pessoa a agir de uma determinada maneira. Este impulso à ação pode ser gerado tanto externamente (ambiente) quanto internamente (processos mentais do individuo). Já os fatores externos desenvolvem-se conforme o ambiente percebe e valoriza o individuo, com remuneração, benefícios sociais, liberdade de idéias, ou seja, os aspectos da organização que levam a diferentes qualidades de motivações nos colaboradores.

São vários os assuntos e temas de interesse da Psicologia Organizacional, entre eles, para interesse deste trabalho destacamos Motivação, Liderança, Saúde Psíquica do trabalhador, os quais serão brevemente abordados a seguir (BOCK, FURTADO, TEIXEIRA, 2000).

As pessoas que não possuem conhecimentos básicos do conhecimento humano acreditam ainda que a maior motivação do homem trabalhar é a remuneração, não que isso seja desconsiderado como importante, mas não sabem elas que o dinheiro é somente o básico para motivação dos funcionários. Isso significa que mesmo o trabalhador ganhando razoavelmente bem, a empresa pode oferecer condições totalmente desumanas, ocasionado a sensibilidade motivacional do colaborador em se desajustar completamente (BERGAMINI, 1982).

Lewis e Person (1964, apud BERGAMINI, 1982, p.127) afirmam:

O incentivo verdadeiramente eficaz é aquele que o trabalhador incorpora a si mesmo e á atitude que assume com relação ao trabalho. Um incentivo é uma meta objetiva capaz de satisfazer alguma necessidade do trabalhador ou algum de seus impulsos e desejos.

Neste caso, se a empresa adotar incentivos apenas de benefícios materiais, como pagamentos extras, bônus etc., o efeito deste ato terminará no instante que for concretizado. Mas se a gestão incentivar seus colaboradores através das necessidades psicológicas, como relações mais satisfatórias dentro da organização tão somente o reconhecimento da produtividade e aplicação dos funcionários etc., torna-se um estímulo mais duradouro e mais eficaz, onde instiga mais prazer por parte dos colaboradores a praticar suas atividades além de oportunizar melhores desempenhos. 
São várias as teorias sobre motivação com perspectivas distintas, mas elas nem sempre se diversificam das ações diferentes sobre o comportamento, mas sim podem ser complementares. Segundo Spector (2002) as Teorias das Necessidades se dividem em três: Teoria da Hierarquia das Necessidades, Teoria ERC e Teoria dos Dois Fatores. As duas primeiras postulam que o comportamento dos indivíduos está interligado com a sua necessidade, ou seja, as ações dos sujeitos são determinadas e empreendidas quando é gerada uma necessidade. Já a terceira teoria afirma que alguns aspectos relacionados ao trabalho estão interligados a dois grupos da necessidade: quanto ao trabalho e quanto a recompensas.

Quanto a Teoria da Hierarquia das Necessidades vale destacar a teoria de Abraham Maslow, que define a hierarquia das necessidades físicas à necessidades psicológicas, sendo elas: fisiológicas (alimentação, sobrevivência), de segurança (estabilidade no emprego), sociais ( amizade), estima (autoconfiança), auto-realização (criatividade). Segundo Spector (2002) essas necessidades estão organizadas em forma de uma pirâmide, de modo que a base desta pirâmide é formada pelas necessidades fisiológicas e o ápice dela está a necessidade de auto-realização. As necessidades de sobrevivência são preponderantes às demais. Vale ressaltar que as necessidades primeiras a serem buscadas a satisfação pelos indivíduos são aquelas que estão nos níveis mais baixo da pirâmide, de modo que o indivíduo só buscará satisfazer as necessidades superiores quando as inferiores estiverem satisfeitas.

Outras Teorias também abordam e explicam o modo de funcionamento da Motivação. A Teoria do Reforço tem por princípio afirmar que o resultado do comportamento é que determina a repetição ou não do comportamento. Para esta teoria o elemento motivador é fornecido por processos ambientais, como recompensas. Esta teoria é também bastante utilizada em sistemas organizacionais. A Teoria da Expectativa, que busca explicar a causa do comportamento pelo qual é influenciado pelas recompensas. Outra teoria é a da Auto-Eficácia que analisa de que modo a confiança na capacidade dos indivíduos afeta seus comportamentos. Já a Teoria da Equidade considera os valores pessoais em vez das necessidades, como igualdade e justiça nas relações com outras pessoas e com as organizações. A Teoria da Fixação de Metas explicam como os objetivos pessoais e as metas conscientes podem incentivar a ocorrência de um dado comportamento (SPECTOR, 2002).

Quanto à questão da Saúde Psíquica do Trabalhador, muitos profissionais ainda acreditam que a empresa que faz uso de serviços de um psicólogo organizacional esta perdendo tempo e dinheiro, afinal julgam que psicólogos são para "loucos" e não para 
funcionários "normais". Porém, psicólogos organizacionais auxiliam no sentido de identificar sinais de transtornos mentais, como stress, síndromes etc., além de "promover a saúde mental" no profissional, assim como propõe estratégias de prevenção dos males do trabalho. Fiorelli (2004, p. 308) esclarece: “Transtornos mentais ocorrem em profissionais de todos os níveis e capacidades: enfrentá-los é uma inteligente estratégia para aumentar a competitividade e a produtividade, prevenindo seus efeitos multiplicativos". Embora ainda haja bastante preconceito quanto a este aspecto, é fundamental a conscientização das empresas de que promover a saúde mental é mais viável do que estar sujeito as consequiências trazidas pelos transtornos mentais, nos quais atinge toda organização. Assim, o psicólogo organizacional deve atribuir-se a esta extraordinária tarefa.

Além destes e outros fatores serem fundamentais para organização, a liderança também se destaca. Como afirma Fiorelli (2004, p.200) "Sem liderança, não há Organização. (...) Liderança é capacidade que algumas pessoas possuem de conseguir que outras, de modo espontâneo, ultrapassem o estabelecimento formalmente".

Para ser um bom líder deve-se demonstrar através de seus comportamentos: expansividade, inteligência, estabilidade emocional, entusiasmo, ousadia, sensibilidade confiança, imaginação, espírito critico, senso de justiça, disciplina. Além dessas qualidades é importante que um líder tenha algumas habilidades, lembrando que habilidade é conhecimento posto em prática, sendo: habilidade para observar, para escutar, para falar, envolvimento, compreensão, expressão corporal, habilidade para orientar etc. (FIORELLI, 2004).

\subsection{Perspectivas da Disciplina de Psicologia}

As empresas que almejam sucesso devem estar abertas às mudanças. Assim, um profissional contábil tem que estar preparado para modificações tecnológicas, estando ciente que atualmente não basta um contador apenas dominar números, mas é necessário ter o domínio em relações humanas e estar consciente das movimentações globais nos mais diversos setores. Assim, as instituições educativas, como exemplo, a UNEMAT, têm por compromisso preparar os futuros gestores para reconhecer a importância de cada disciplina incluída na Matriz Curricular.

A Disciplina de Psicologia é muito ampla e ao mesmo tempo complexa por proporcionar campos abrangentes, mas em geral ela possui um único objetivo: analisar e compreender o comportamento humano. Ela nos proporciona condições de lidar com os 
nossos familiares, com os nossos gestores, com os nossos clientes, enfim com o nosso próximo, sem que haja em nos medo para enfrentá-los (FIORELLI, 2004).

De acordo com o plano de ensino da UNEMAT de Tangará da Serra-MT, disponível no site do Departamento de Ciências Contábeis da UNEMAT/2011, o objetivo da Disciplina de Psicologia para os acadêmicos de contabilidade, são:

\footnotetext{
-Proporcionar ao acadêmico acesso aos referenciais teóricos que subsidiam a compreensão de comportamento humano nas organizações;

-Possibilitar a reflexão e análise do indivíduo no contexto organizacional desenvolvendo criticidade e reflexão na práxis do profissional de Ciências Contábeis;

-Refletir sobre a situação do trabalhador nas relações de trabalho e sociedade de modo a contribuir para as decisões do profissional.
}

Afinal, atualmente um contador bem sucedido, é ao mesmo tempo um administrador para oferecer comunicação e entendimento aos seus clientes, é um advogado quando necessita de uma acessória jurídica e um psicólogo para tomar decisões com sabedoria. (FREITAS, 2004).

\subsection{A Importância da Psicologia para o Profissional Contábil}

É fundamental que as pessoas tenham um conhecimento do que é a Psicologia e o que ela influencia em suas vidas. Apesar de essencial, muitos interpretam a Psicologia de uma maneira errônea, causando dificuldades no seu desenvolvimento. Isto ocorre pela falta de conscientização da humanidade em compreender sua extrema importância em nosso cotidiano, que vai além do nosso trabalho e família, compreendermos o EU (autoconsciência, consciência da essência humana). (BOCK, FURTADO, TEIXEIRA, 2000).

Em todo setor de trabalho existe uma equipe de profissionais e uma liderança onde há necessidade de saber reagir e interagir com as pessoas de seu meio profissional ou social. Embora lidar com o imprevisível e indecifrável ser humano seja difícil, levando em consideração a oscilação emocional, cultura familiar e etc., trará constante aprendizado aos membros dessa equipe (CHIAVENATO, 2006). Da mesma maneira ocorre com o profissional de contabilidade que precisa da Psicologia constantemente para desenvolver o equilíbrio emocional das pessoas envolvidas e obter um bom desempenho no trabalho.

Mas, muitas pessoas acreditam que seria mais viável para uma empresa contratar serviços de um psicólogo para auxiliar os colaboradores em suas perspectivas. Freitas (2004) explica que um psicólogo por não fazer parte das atividades da empresa diariamente poderá deixar em lacunas a verdadeira situação da empresa, principalmente se for financeiramente, 
transmitindo para os funcionários desconfiança. Assim, seria mais conveniente o profissional contábil que participa efetivamente das atividades da empresa, lidar com seus colaboradores, até porque a confiança de um gestor da própria empresa é mais aplicável do que um gestor desconhecido.

Deste modo, é recomendável e indispensável que o profissional contábil além de se munir de conhecimentos e habilidades técnicas esteja também preparado para o trabalho e relações com sua clientela, com os funcionários e consigo mesmo. Do mesmo modo é imprescindível que o profissional de Ciências Contábeis, em contextos atuais, desenvolva as habilidades técnicas gerenciais no que se refere aos recursos humanos, conforme sinaliza Freitas (2004).

Um excelente profissional é aquele que sabe ouvir e demonstrar seu papel no momento exato, considerando que sempre estará defronte a diferentes empresários e diferentes pessoas de outras posições. Portanto, é essencial que o profissional, seja ele contador ou não, mantenha o equilíbrio psíquico exercitando a autocrítica, auto-estima entre outros fenômenos psicológicos tornando-se maleável, solidário, sensível, compassível, paciente no exercício de sua profissão (CHIAVENATO, 2006).

\section{METODOLOGIA}

Para o desenvolvimento deste trabalho foram utilizadas diferentes técnicas de coleta, análise e compreensão dos dados. Segundo Vergara (2004) uma pesquisa científica pode ser classificada e compreendida quanto a seus fins e quanto aos meios utilizados. Desta forma, a pesquisa quanto aos fins, se caracterizou como pesquisa descritiva, a qual "expõe características de determinada população ou determinado fenômeno" (VERGARA, 2004, p. 47). Segundo Oliveira (2000, p.114) esta metodologia é um estudo que possibilita o pesquisador na "obtenção de uma melhor compreensão do comportamento de diversos fatores e elementos que influenciam determinado fenômeno".

Também quanto aos fins, a pesquisa é considerada exploratória, sobre a qual Vergara (2004, p. 47) afirma que é "realizada em área na qual há pouco conhecimento acumulado e sistematizado", portanto não há hipótese inicialmente, tendo em vista que a investigação buscou identificar de que modo os acadêmicos do curso de Ciências Contábeis da UNEMAT - Tangará da Serra percebem a influência da disciplina de Psicologia na sua formação.

Quanto aos meios, ou seja, de que modo se realizou o estudo, pode-se compreender esta investigação como estudo de caso, que segundo Gil (2000, p.58) consiste no "estudo 
profundo e exaustivo de um ou de poucos objetivos, de maneira a permitir seu conhecimento amplo e detalhado." Neste caso, foi focado o caso dos acadêmicos do curso de Ciências Contábeis da UNEMAT e sua percepção acerca da influência da disciplina de Psicologia em sua formação. Assim, para este tipo de metodologia é comum se utilizar de algumas técnicas de coleta de dados, como "entrevistas estruturadas ou não, questionário, observações dos fatos, análise documental" (SILVA, 2003, p.63), podendo ser o objeto da pesquisa o indivíduo, uma organização, uma situação etc. Desta forma, foram aplicados 123 questionários, cada um contendo 19 perguntas, aos alunos que já estão cursando semestres mais avançados no curso, no caso, o quarto, quinto, sexto, sétimo e oitavo semestre, totalizando 123 alunos. Esta população se justifica pelo fato de que é no terceiro semestre que os acadêmicos cursam a disciplina em foco.

Este estudo contou ainda com estudos bibliográficos, que, é definido como "estudo sistematizado desenvolvido com base em material publicado em livros, revistas, jornais, redes eletrônicas, isto é, material acessível ao publico em geral.” (VERGARA, 2004, p. 48). Deste modo, além de artigos que divulgam pesquisas recentes, também através de renomados autores, se buscou subsídios para compreensão e discussão do tema em foco. Foram referências teóricas autores como Ana Maria Bock, Cecília Whitaker Bergamini, Idalberto Chiavenato, José Carlos Marion, Sylvia Constant Vergara, Antônio Carlos Gil, entre outros, que apresentam conhecimentos diversificados que muito contribuíram com o desenvolver deste estudo. Além da busca pelos referenciais teóricos, foram utilizados também documentos institucionais para coleta de dados.

Enfim, para complementar, a pesquisa segue uma abordagem qualitativa e quantitativa que de acordo com Longaray et al (2003, p.91): "A abordagem qualitativa visa destacar características não observadas por meio de um estudo quantitativo". Já a quantitativa Oliveira (2001, p.115) esclarece que:

Significa quantificar opiniões, dados, nas formas de coleta de informações, assim como também com o emprego de recursos e técnicas estatísticas desde a mais simples, como porcentagem, média, moeda, mediana e desvio padrão, até as de uso mais complexo, como coeficiente de correlação, análise de regressão etc. normalmente utilizados em defesas de teses.

\section{RESULTADOS E DISCUSSÃO}

Esta seção apresenta os resultados da coleta de dados junto aos acadêmicos do curso de Ciências Contábeis do Campus Universitário da UNEMAT de Tangará da Serra, assim como faz a discussão dos resultados. Os dados foram tabulados de forma quantitativa, 
utilizando-se uma planilha para unificação e cálculo dos resultados obtidos. O público pesquisado tem faixa etária entre 18 a 42 anos, sendo que $70(56,9 \%)$ variam entre 18 a 23 anos de idade, conforme Figura 1 (C) a qual é representada em sua maioria pelo sexo masculino (53\%) conforme Figura 1 (B). Do total dos entrevistados, 17,9 \% cursam o quarto semestre, $20,3 \%$ o quinto semestre, $24,4 \%$ estão cursando o sexto semestre, 19,5\% cursam o sétimo semestre e, por fim, $17,9 \%$ estão no oitavo semestre do curso de Contábeis, cujos resultados encontram-se expressos na Figura 1 (A).

De todos os entrevistados, $98 \%$ já concluíram a disciplina de Psicologia, conforme Figura 1(D), dado extremamente importante, já que esta pesquisa se baseia nos entrevistados que tem conhecimento desta disciplina.

FIGURA 1: Percentual de acadêmicos por Semestre (A), Sexo (B), Idade (C) e Cursaram a Disciplina de Psicologia (D) na UNEMAT de Tangará da Serra-MT.

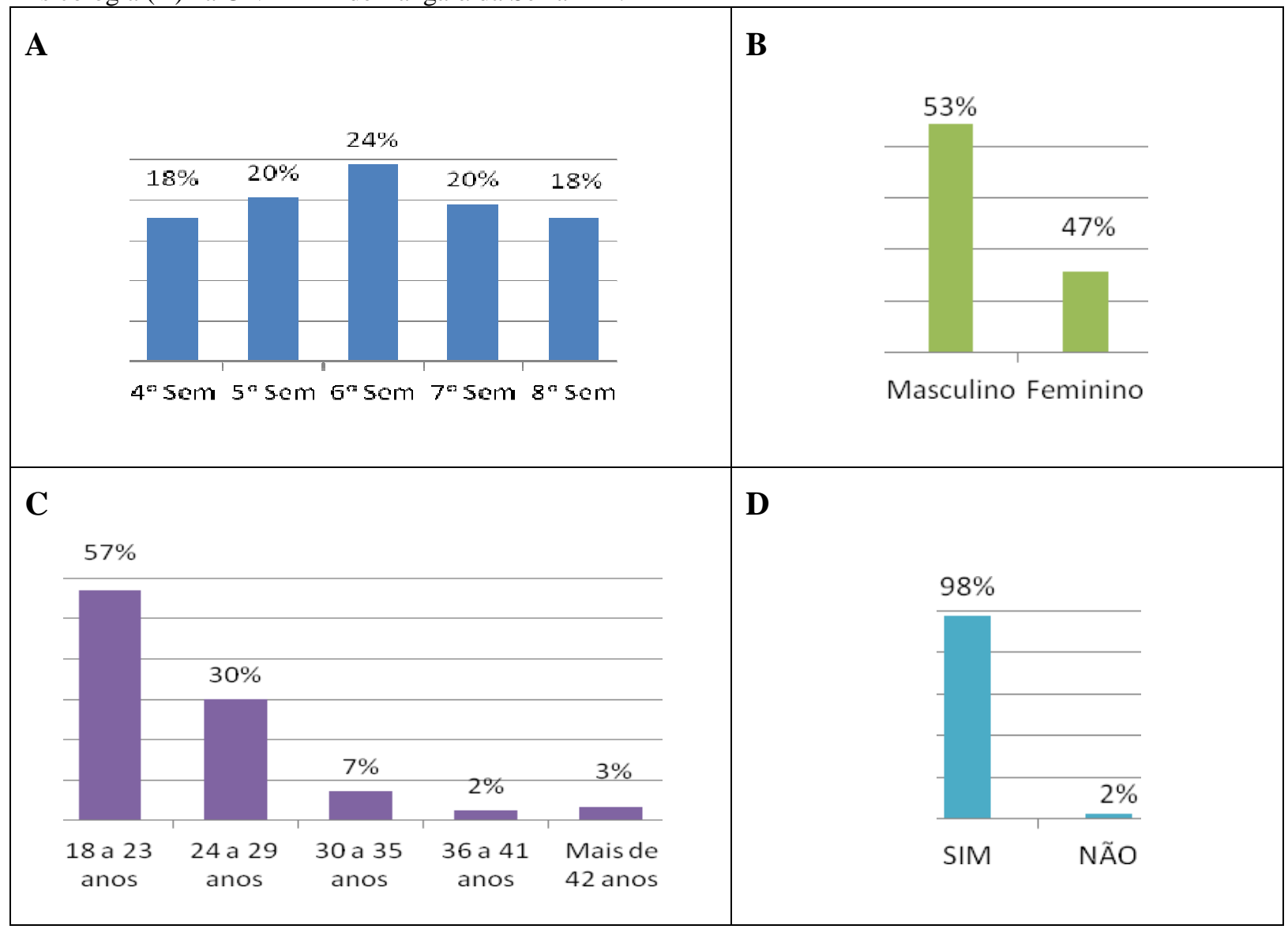

Fonte: Dados da pesquisa.

\subsection{Influências Psicologia no Aspecto Pessoal}

Ressaltando a afirmação de Fiorelli (2004), citada no decorrer deste artigo, a maioria dos psicólogos considera a Psicologia como a ciência que estuda o comportamento humano, 
seja ele visível ou não. Podem-se considerar, assim, diversos comportamentos como: familiares, escolares, organizacionais, culturais, psíquicos e etc. A família "é responsável pela sobrevivência física e psíquica das crianças, constituindo-se no primeiro grupo de mediação do indivíduo - daquele bebê, que está ali no berço - com a sociedade" (BOCK, FURTADO, TEIXEIRA, 2000). É a partir daí, que se observa a importância da família e sua indispensável interação, afinal, é ela a forte transmissora de valores culturais e ideológicos.

Pode-se observar que os acadêmicos pesquisados são bem integrados com a família, considerando que $7 \%$, Figura 2 (B), moram sozinhos e 82\% (conforme Figura 2 (B)) possuem um bom relacionamento com as pessoas que moram e apenas $1 \%$, Figura 2 (B), dos pesquisados tem um relacionamento desagradável (ruim) com as pessoas no ambiente onde convive. Apesar de existir várias famílias com suas diferenças e estruturas distintas na sociedade é fundamental destacar que "a família é o primeiro grupo, a primeira escola, a primeira comunidade e a primeira experiência de exercício da cidadania que todo indivíduo vivencia, sendo essa experiência profundamente marcante" (MILANI, 2011).

Ao perguntar se os entrevistados dialogavam com seus familiares, obteve-se um percentual de 86,2 \%, Figura 2 (D), de resposta "sim", afirmando que realmente a maioria dos pesquisados possuem um bom relacionamento com suas famílias. Porém, como nem todas as pessoas pensam iguais, mas defendem suas idéias, dos entrevistados, conforme se pode acompanhar na Figura 2 (C), 22\% afirmam que conflitam com as pessoas com as quais convivem, $21 \%$ apresentam este comportamento com freqüência razoável, $1 \%$ informam que sempre e $51 \%$ responderam que não conflitam.

FIGURA 2: Quantidade de pessoas que moram (A), Relacionamento com as pessoas que moram (B), Costuma ter conflitos com pessoas que convivem (C) e Costuma dialogar com a família (D).

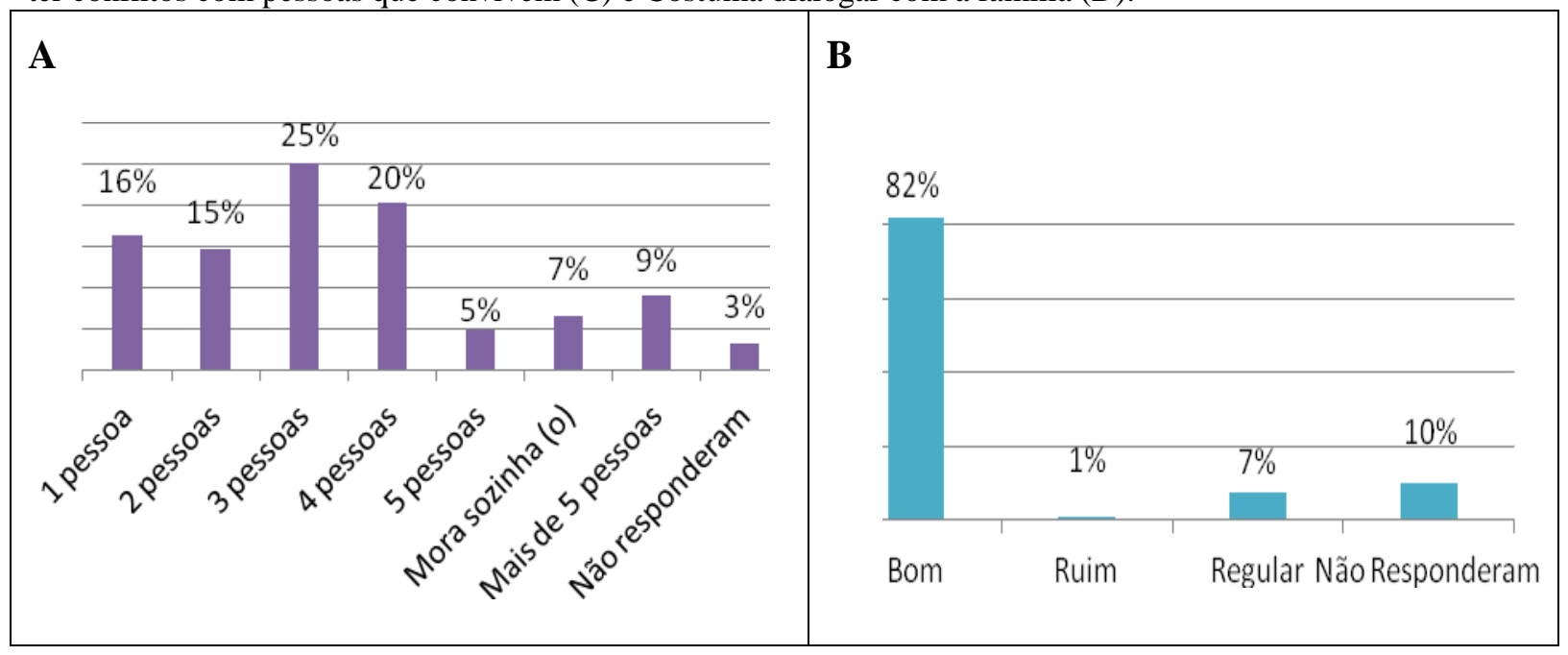




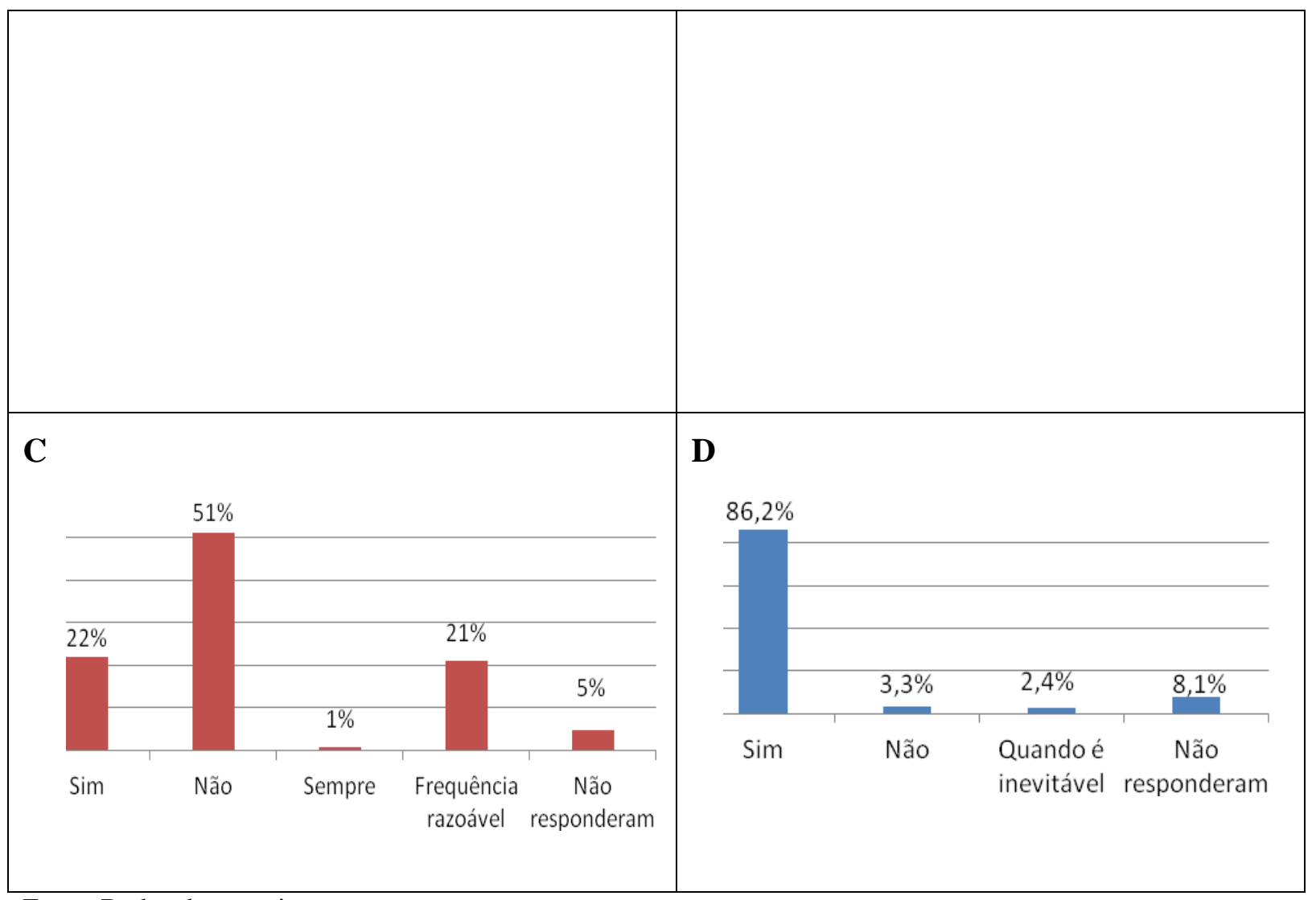

Fonte: Dados da pesquisa.

\subsection{Influências da Psicologia no Aspecto Profissional}

Dos pesquisados a grande maioria (89 \%) trabalha em emprego formal, cuja diversidade do setor de atividade econômica varia na maior parte. Destes, apenas 22\% trabalham na área contábil, $19 \%$ no setor de administração, $8 \%$ no setor financeiro e praticamente metade (47 \%) atuam em atividades diversificadas, sendo que 4\% não responderam.

Conforme a Figura 3 (D) destaca-se um fator extremamente importante para as organizações: a liderança. Dos acadêmicos entrevistados $80 \%$ responderam que têm um bom relacionamento com os seus chefes, considerando que 4\% não responderam e $11 \%$ tem um relacionamento razoável. Desta forma, pode-se inferir que grande parte dos chefes dos entrevistados pode ser considerado líder, segundo a tese de Fiorelli (2004) quando afirma que para ser um bom líder deve-se mostrar qualidades através de seus comportamentos e habilidades como: falar, ouvir, compreender etc. Estabelecer e manter bom relacionamento com a equipe de trabalho é uma das fortes características da liderança. 
Ainda podemos enfatizar outro fator importante, o qual se estende a um dos objetivos da Psicologia Organizacional, sobre o qual Fiorelli (2004) afirma que é estudar meios de evolução no ambiente organizacional quanto à compreensão pelos administradores dos processos que os envolve. Desta forma, fica claro que estes líderes consideram a Psicologia Organizacional já que um desses processos é manter um bom relacionamento com seus funcionários.

Observa-se que os entrevistados também se relacionam bem com os seus colegas de trabalho apontando um percentual de 88,6 \%, conforme Figura 3 (C), considerando que 5,7\% não responderam e apenas 3,3\% afirmam que não possuem um bom relacionamento com os mesmos. Como Levine (2005) afirma: "Para ser bem sucedido e viver uma vida feliz e proveitosa, você precisa da ajuda dos outros. Ninguém pode viver sozinho. Família, amigos, colegas, funcionários, clientes - todos têm a capacidade de enriquecer a nossa vida”. Afinal, investir em relações é como investir em dinheiro, você recebe o retorno.

FIGURA 3: Trabalha atualmente (A), Setor na Atividade que Trabalha (B), Relaciona-se bem com os colegas de Trabalho (C) e Relaciona-se bem com o chefe (s) (D).

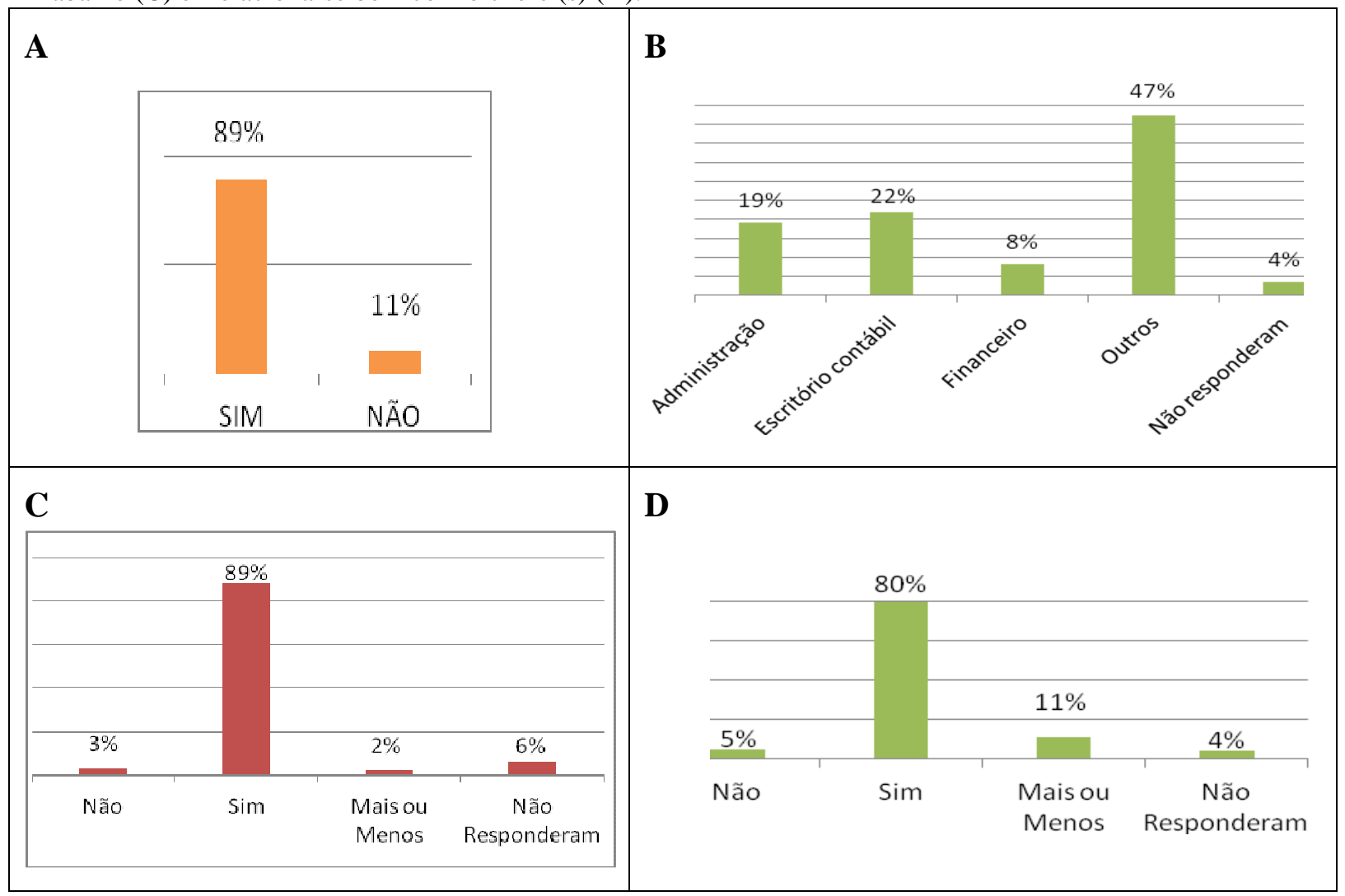

Fonte: Dados da pesquisa.

Tendo em vista o público alvo ser futuros contadores perguntou-se para os que já atuam na área contábil como julgam a importância do bom relacionamento com os colegas de 
trabalho. Indagação necessária, já que Freitas (2011) argumenta que para uma boa gestão dentro de uma organização é importante que o contador também domine os aspectos que abrangem a área de Psicologia. Ao observar a Figura 4 (B) pode-se notar que praticamente $60 \%$ dos futuros contadores julgam necessário se relacionar bem com seus colegas de trabalho, considerando um percentual de $38 \%$ dos entrevistados que não responderam. Este percentual de acadêmicos que não responderam é fator importante, pois pode indicar certa insegurança quanto a este quesito de relações no trabalho.

Meditando nos dados obtidos na Figura 4-A, vale ressaltar que os contadores concordam que o relacionamento na organização é fundamental para quem atua na área, afirmando assim a tese de Freitas (2011), já que $68 \%$ destes trabalham diretamente com o público (considerando $2 \%$ não respondidos) e apenas $16 \%$ acreditam não ser necessário obter relacionamentos com seus colegas de trabalho.

FIGURA 4: Relaciona-se diretamente com o público (A), Se trabalha escritório Contábil, concorda em ter um bom relacionamento com os colegas de Trabalho (B)

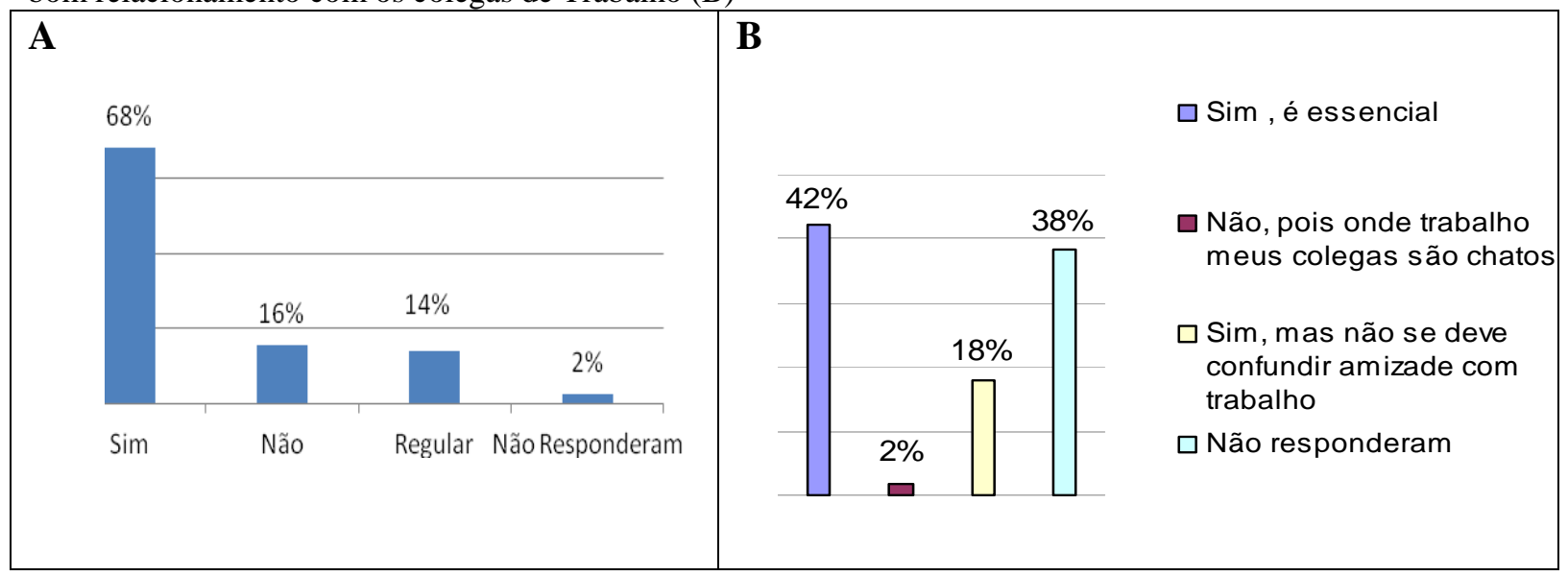

Fonte: Dados da pesquisa.

Outro objetivo da psicologia citado nesta pesquisa por Fiorelli (2004) destaca-se: Desvendar os mecanismos que lhe servem de apoio para os fatos que surgem a partir do senso psicológico, exemplo, stress. Fator que serviu de apoio para esta pesquisa, destacando a importância da Psicologia Organizacional para os contadores, devido ao fato, da maioria (41\%), conforme Figura 5, dos pesquisados responderem que se estressam no trabalho e apenas $4 \%$ afirmarem que não se estressam. Sendo assim, com fundamentos psicológicos não só em relação aos contadores, mas também em qualquer área profissional, podem-se controlar fatores extremos (como estresse, pânicos etc.) possivelmente gerados nas organizações.

FIGURA 5: Lugar onde mais se estressa. 


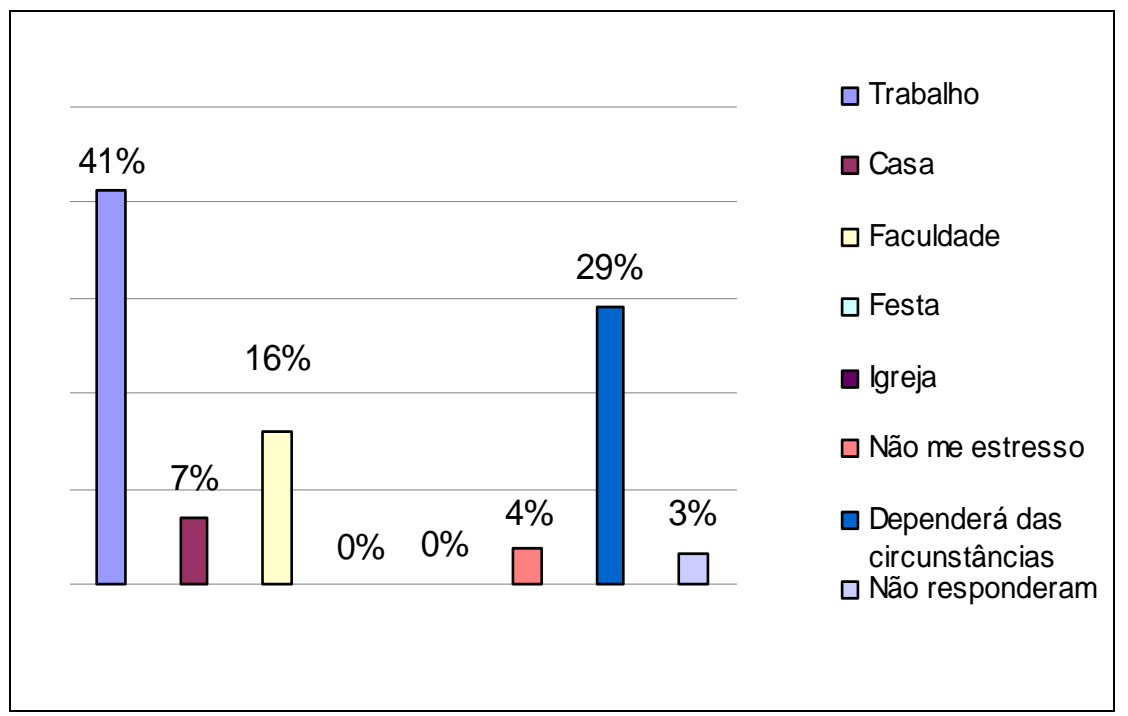

Fonte: Dados da pesquisa.

\subsection{Influências da Disciplina de Psicologia Organizacional}

A função da disciplina de Psicologia é auxiliar os acadêmicos à "reflexão e análise dos aspectos operacionais na organização, considerando as dinâmicas do comportamento humano e organizacional de modo a auxiliar no processo de decisão do profissional de Ciências Contábeis (DEPARTAMENTO DE CIÊNCIAS CONTABEIS/UNEMAT, 2011). Através deste objetivo proposto pela UNEMAT, é considerável afirmar que houve êxito na pesquisa ao buscar compreender qual a importância da disciplina para os acadêmicos de Ciências Contábeis tanto nos aspectos do comportamento profissional quanto do comportamento pessoal, ao analisar com mais ênfase os dados apresentados nas Tabelas 1 e 2. Dos entrevistados, 34 acadêmicos afirmam que a após cursar a disciplina de Psicologia não houve mudança em seus comportamentos profissionais (considerando $0,3 \%$ não responderam). Entretanto, dos que responderam (Tabela 1) $18,1 \%$ admitem que os relacionamentos interpessoais no trabalho melhoraram, 15,2\% acreditam lidar melhor com alguns aspectos do trabalho, $14,1 \%$ começaram a entender aspectos e comportamentos da liderança da chefia, 13,2 \% reconheceram a importância da motivação, entre outros. Enfim, tais respostas são amparadas por Berganini (1982, p.20) ao argumentar que o objetivo da Psicologia Organizacional é "aprofundar-se no estudo do homem em situação de trabalho de forma generalizada".

Quanto aos comportamentos pessoais, 42 alunos consideram que a disciplina de Psicologia não os alterou, considerando que $1 \%$ optou não responder. Contudo, dos respondentes (Tabela 2) 15\% asseguram que após cursar Psicologia passaram a reconhecer os 
limites de cada um, 14,4\% respeitam o pensamento/posicionamento dos outros, 13,7\% relaciona-se melhor com os colegas, $13,4 \%$ analisa mais detalhadamente antes de julgar o comportamento alheio, $13,1 \%$ considera que houve uma melhor relação com os familiares, respeitam a maneira de viver do próximo e passaram a compreender que cada pessoa tem uma reação diferenciada para mesmas situações.

TABELA 1: Após cursar a Disciplina de Psicologia, Aspectos que mudaram no comportamento Profissional.

\begin{tabular}{|c|c|}
\hline Aspectos que mudaram no comportamento Profissional & $\%$ \\
\hline Relacionamentos interpessoais & $18,1 \%$ \\
\hline Reconhecer a importância da motivação & $13,2 \%$ \\
\hline Reconhecer o lado humano das organizações & $9,2 \%$ \\
\hline Lidar melhor com alguns aspectos do trabalho & $15,2 \%$ \\
\hline Compreender possíveis doenças relacionadas ao trabalho & $6,0 \%$ \\
\hline Compreender aspectos e comportamentos da liderança da Chefia & $14,1 \%$ \\
\hline Reconhecer a diversidade que caracteriza o individuo humano & $12,4 \%$ \\
\hline Considerar o fator humano para tomada de decisões & $11,5 \%$ \\
\hline Não responderam & $0,3 \%$ \\
\hline & $100,0 \%$ \\
\hline
\end{tabular}

Fonte: Dados da pesquisa.

TABELA 2: Após cursar a Disciplina de Psicologia, Aspectos que mudaram no comportamento Pessoal.

\begin{tabular}{c|c}
\hline \multicolumn{1}{c|}{ Aspectos que mudaram no comportamento Pessoal } & $\%$ \\
\hline \hline Relação com familiares & $13,1 \%$ \\
\hline \hline Educação com os filhos & $3,3 \%$ \\
\hline \hline Reconhecer os limites de cada um & $15,0 \%$ \\
\hline \hline Relação com colegas & $13,7 \%$ \\
\hline \hline
\end{tabular}




\begin{tabular}{c|c}
\hline \hline Compreender que cada pessoa tem um modo específico de viver & $13,1 \%$ \\
\hline \hline Compreender que cada pessoa reage diferente de mim às mesmas situações & $13,1 \%$ \\
\hline \hline Me colocar no lugar do outro antes de julgar seu comportamento & $13,4 \%$ \\
\hline \hline Não responderam & $1,0 \%$ \\
\hline \hline
\end{tabular}

Fonte: Dados da pesquisa.

No site oficial da UNEMAT de Tangará da Serra-MT está disponível a Ementa da Disciplina de Psicologia para o curso de Ciências Contábeis/2011, conforme segue.

Contextualização histórica da Psicologia e sua evolução enquanto ciência psicológica para compreender as principais forças teóricas deste campo de estudos: Behaviorismo e Psicanálise. A Psicologia Organizacional e seus temas de interesse que impactam nas tomadas de decisões do Profissional de Ciências Contábeis: Motivação; Recrutamento e Seleção; Avaliação de desempenho; Relações Humanas na organização; O poder nas organizações; Diversidade cultural no contexto organizacional; Saúde mental e Trabalho.

Após cursarem a Disciplina de Psicologia na UNEMAT a maioria (53\%) dos respondentes considera os contextos da Psicologia muito relevante (Figura 6-A), levando em consideração o percentual de $2 \%$ que preferiram não responder. Do total, 42\% (Figura 6-A) percebem a disciplina com pouca relevância e a minoria (3\%) acha irrelevante. Todavia, ao questionar os motivos para Disciplina de Psicologia fazer parte do curso de Contábeis na UNEMAT, surpreende-se que apenas $4 \%$ (Figura 6-B) defendem que não há motivos.

De acordo com a pesquisa nota-se que os futuros contadores defendem que a Disciplina em questão deve manter-se no curso, estes, até dão motivos para tal, conforme a Figura 6-B: $34 \%$ apoiam a Disciplina no curso, pois destacam as principais teorias que explicam o modo como nos comportamos; $31 \%$ pois estuda o comportamento humano instruindo a um comportamento projetado; $23 \%$ pela disciplina ensinar a respeitar o próximo, tão somente, compreende-los e $8 \%$ acham que é apenas mais uma matéria para preencher a grade do curso de Ciências Contábeis.

FIGURA 6: Relevância do ensino quanto às questões da Psicologia (A), Motivos para Disciplina de Psicologia fazer parte do curso de Contábeis na UNEMAT (B). 

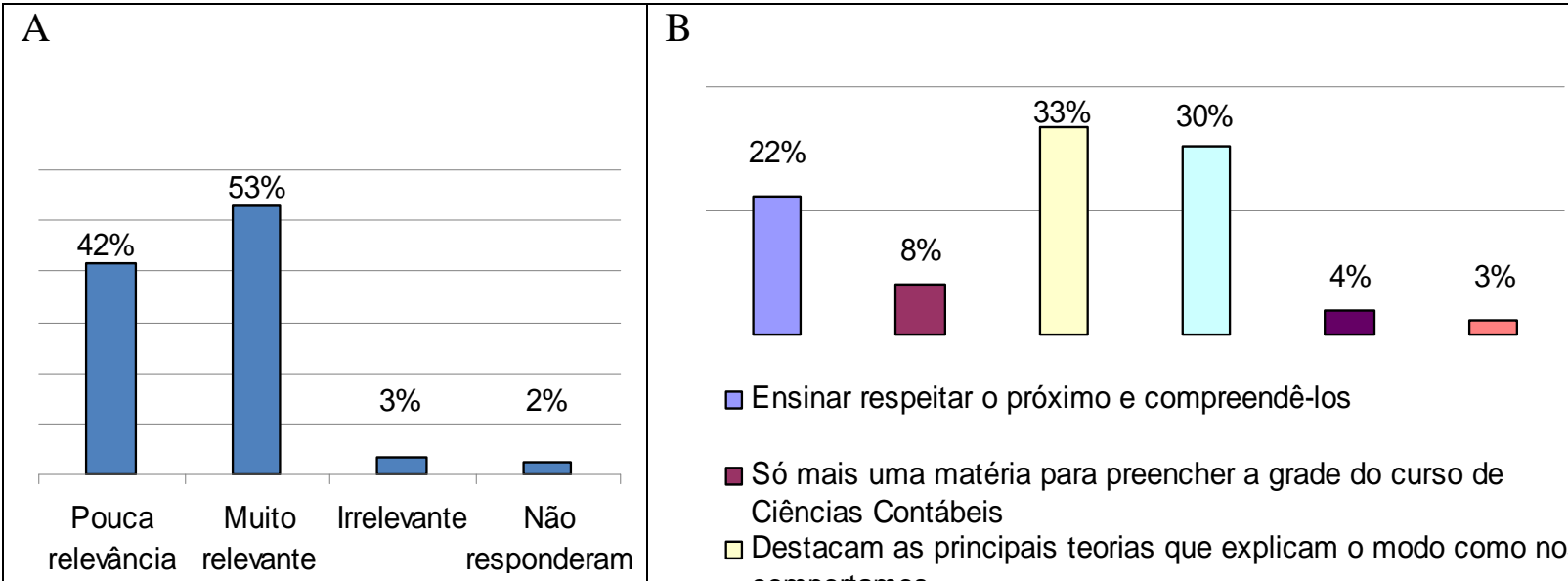

$\square$ Ensinar respeitar o próximo e compreendê-los

$\square$ Só mais uma matéria para preencher a grade do curso de Ciências Contábeis

$\square$ Destacam as principais teorias que explicam o modo como nos comportamos

$\square$ Estuda o comportamento humano instruindo a um

comportamento projetado

$\square$ Não há motivos

$\square$ Não responderam

Fonte: Dados da pesquisa.

Pode-se considerar fundamental a Disciplina de Psicologia no curso de Ciências Contábeis na UNEMAT, de acordo com os próprios acadêmicos respondentes. Conforme a Figura 7 evidencia, $89 \%$ dos estudantes garantem que é essencial a Disciplina de Psicologia permanecer na grade do curso de Contábeis e apenas $11 \%$ discordam.

FIGURA 7: Disciplina de Psicologia deveria permanecer na grade do curso de Ciências Contábeis.

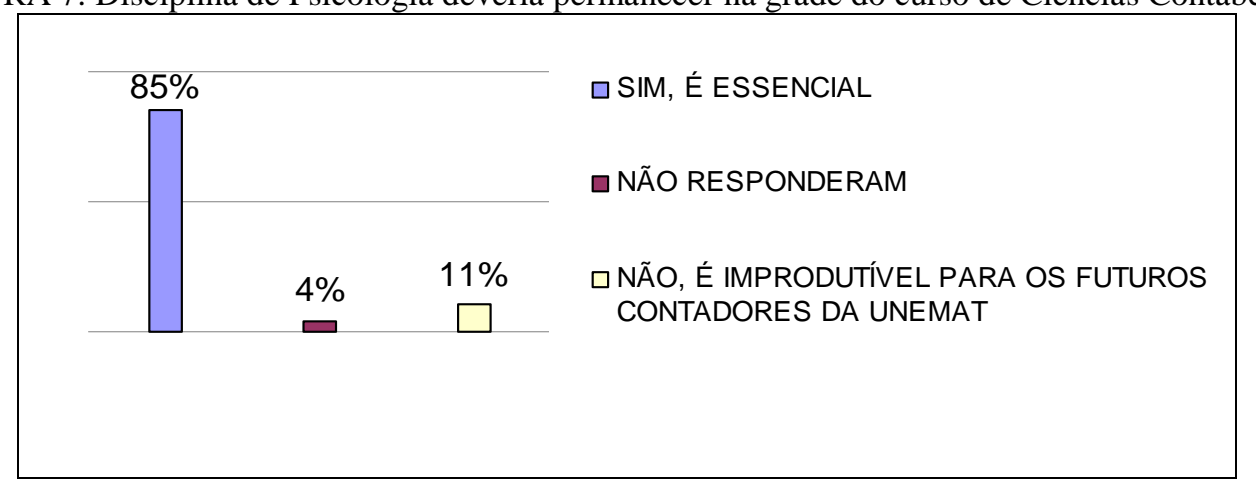

Fonte: Dados da pesquisa.

\section{CONSIDERAÇÕES FINAIS}

A análise geral dos resultados alcançados na pesquisa induziu a resposta do problema proposto nesta pesquisa, através das seguintes considerações: Após cursar a disciplina de Psicologia, os respondentes obtiveram melhores relacionamentos pessoais e profissionais, independentemente dos setores de atividade que atuam; dos acadêmicos pesquisados que já 
atuam na área contábil, a maioria considera importante ter um bom relacionamento com os colegas de trabalho; os respondentes consideram que a disciplina de Psicologia é importante por destacar teorias que explicam o modo pelo qual nos comportamos, por ensinar a respeitar e compreender as pessoas, entre outras razões; mais da metade dos discentes considera relevante o ensino de questões psicológicas no curso de Ciências Contábeis.

Analisando mais detalhadamente a Figura 6 (A), conclui-se que parte dos acadêmicos possui um conhecimento da essência da Psicologia, sendo que a maioria afirma que a disciplina estuda e analisa o comportamento humano.

Vale ressaltar que os objetivos deste trabalho foram alcançados, em virtude dos resultados obtidos na pesquisa, a qual demonstrou a relevância que os estudantes atribuem às questões da Psicologia e a consideração pela disciplina como um aperfeiçoamento educacional. Sendo assim, o destaque da importância imposta pelos acadêmicos aos assuntos da Psicologia para sua formação profissional e pessoal pode contribuir não só para a UNEMAT, mas também para as demais instituições acadêmicas que oferecem o curso de Ciências Contábeis, o quanto a disciplina de Psicologia é significativa para os futuros contadores, de acordo com os próprios estudantes.

\section{REFERÊNCIAS}

A.P.Contabilidade. História da Contabilidade. Disponível em:

<http://www.apcontabilidade.com.br/historiacontabilidade.htm>. Acesso em: 27 março 2011.

BERGAMINI, Cecília Whitaker. Psicologia aplicada à administração de empresas. $3^{\circ}$ edição. São Paulo: Atlas, 1982.

BOCK, Ana Mercês Bahia; FURTADO, Odair; TEIXEIRA, Maria de Lourdes Trassi. Psicologias: uma introdução ao estudo de Psicologia. 13º edição. São Paulo: Saraiva, 1999. BRAGHIROLLI, Elaine Maria; BISI, Guy Paulo; RIZZON, Luiz Antônio; NICOLETTO, Ugo. Psicologia Geral. 15º edição. Petrópolis: Vozes, 1998.

CHIAVENATO, Idalberto. Recursos Humanos: O Capital Humano das Organizações. $8^{\circ}$ edição. São Paulo: Atlas, 2006.

Covest. Concorrência do Concurso Vestibular 2008/1. Disponível em: $<$ http://www.unemat.br/vestibular/downloads/vest_2008_1/documentos/vestibular_20081 _concorrencia_vertical.pdf.> Acesso: 21 abril 2011.

Departamento de Ciências Contábeis - UNEMAT - Tangará da Serra. Histórico. Disponível em: 〈https://sites.google.com/a/unemat.br/cictga > Acesso: 19 abril 2011.

FIORELLI, José Osmir. Psicologia para Administradores. $4^{\circ}$ edição. São Paulo: Atlas, 2004. 
FREITAS, Rodrigo. Artigo: Psicologia Contábil. Disponível em: $<$ http://www.contabeis.com.br/artigos/8/psicologia-contabil/.htm $>$ Acesso em: 27 março 2011.

GIL, Antônio Carlos. Técnicas de Pesquisa em economia e elaboração de monografia. $3^{\circ}$ Edição. São Paulo: Atlas, 2000.

LEVINE, Stuart R. Seis fundamentos do sucesso profissional. Rio de Janeiro: Sextante, 2005.

LONGARAY et al. Como Elaborar Trabalhos Monográficos em Contabilidade: Teoria de Prática. São Paulo: Atlas, 2003.

MILANI, Feizi M. Adolescência e violência: mais uma forma de exclusão. Disponível em: $<$ http://www.educaremrevista.ufpr.br/arquivos_15/milani.pdf $>$ Acesso: 20 agosto 2011.

Noticia Exata. Disponível em: $<$ http://www.noticiaexata.com.br/index.php/educacao/2011/1.html.>Acesso: 21 abril 2011.

OLIVEIRA, Silvio Luiz. Tratado de metodologia Cientifica: Projetos de Pesquisa, TGI, TCC, Monografia, Dissertações e Teses. $2^{\circ}$ edição. São Paulo: Pioneira Thomson Learning, 2001.

PINTO, Larissa Cavalcanti de Sá. A formação acadêmica do Contador para o mercado atual. Disponível em: 〈http://www.facape.br/socrates/Trabalhos/Contador.htm> Acesso: 28 abril 2011.

PRESTES, Maria Luci de Mesquita. A pesquisa e a construção do conhecimento científico: do planejamento aos textos, da escola à academia. $2^{\circ}$ edição. São Paulo: Rêspel, 2003.

SCHMIDT, Paulo. História do pensamento contábil. Porto Alegre: Bookmann, 2000.

SPECTOR, Paul E. Psicologia nas Organizações. $2^{\circ}$ edição. São Paulo: Saraiva, 2002.

VERGARA, Sylvia Constant. Projetos e Relatórios de Pesquisa em Administração. $5^{\circ}$ edição. São Paulo: Atlas, 2004. 